\title{
INOVASI DALAM PEMBELAJARAN MATA KULIAH PRAKTIKUM BAHASA INGGRIS DI STAIN KUDUS
}

\author{
Azizah Maulina Erzad \\ STAIN Kudus, Jawa Tengah, Indonesia \\ azizahmaulinae@gmail.com
}

\begin{abstract}
Abstrak
Penulisan artikel ini dilatarbelakangi oleh semakin berkembangnya teknologi dan informasi yang meningkat dengan bebas. Atas dasar tersebut, penulis memandang bahwa perkembangan teknologi ini harus dapat dimanfaatkan dengan sebaik-baiknya oleh guru dalam dunia pendidikan. Penelitian ini, berbentuk penelitian kualitatif dengan pendekatan. Penulis telah mengamati beberapa inovasi dalam pengajaran Praktik Bahasa Inggris yang diterapkan oleh beberapa dosen Bahasa Inggris di STAIN Kudus. Berbagai macam metode telah diterapkan oleh Dosen Bahasa Inggris di STAIN Kudus dalam mengajar Praktikum Bahasa Inggris. Hal ini dipengaruhi oleh berbedanya daya kreativitas masingmasing dosen, sarana atau fasilitas yang dimiliki oleh dosen atau kampus, dan yang lebih utama ialah berbedanya kompetensi dari mahasiswa tiap-tiap kelas, prodi atau jurusan. Sehingga metode yang dipilih pun harus disesuaikan dengan kemampuan dari mahasiswa masing-masing kelas/prodi/jurusan. Inovasi pembelajaran ini dimaksudkan untuk mewujudkan pembelajaran yang aktif, efektif, menyenangkan, dan menarik bagi mahasiswa. Serta yang terpenting yaitu pesan yang ingin disampaikan dosen kepada mahasiswa dapat diterima dan dipahami.
\end{abstract}

Kata kunci: inovasi, praktikum, bahasa Inggris 


\begin{abstract}
LEARNING INNOVATION IN ENGLISH PRACTICUM CLASS IN STAIN KUDUS. The writing of this article was effected by the development of technology and information which increasing freely. On the basis of these, the author looked at that development of this technology should be utilized with the best by the teachers in the world of education. This study is Qualitative research by using analytical descriptive approach. The author had observed some innovation in the teaching of English Practicum which has been applied by English lecturers of STAIN Kudus. A variety of methods have been applied by them in teaching English Practicum. It is influenced by a different power of creativity each lecturer, means or facilities owned by a lecturer or campus, and the more mainstream is the different competencies of students for each class, study program or majors. Therefore, the selected method must be adjusted with the ability of the students of each class/ study program/majors. The learning innovation is intended to embody the learning that is active, effective, fun, and interesting for the students. Furthermore, the most important thing is the message that will be delivered by lecturers to students can be accepted and understood.
\end{abstract}

Keywords: innovation, practicum, English

\title{
A. Pendahuluan
}

Perkembangan zaman yang semakin cepat sekarang ini telah meluas dan menjangkau berbagai negara bahkan sampai ke pelosok negeri di Indonesia. Tidak hanya di perkotaan tetapi juga pedesaaan kemajuan zaman ini dapat kita rasakan dalam kehidupan sehari-hari seperti kemudahan dalam berkomunikasi dan update informasi dari seluruh penjuru dunia. Zaman yang semakin maju dan canggih ini merupakan dampak dari globalisasi dimana semua bidang mengalami kemajuan termasuk infrastruktur transportasi dan telekomunikasi. Globalisasi juga telah berpengaruh pada sektorsektor kehidupan seperti politik, ekonomi, sosial budaya, hankam, dan lain-lain. Demikian pula dalam dunia pendidikan yang juga mengalami perkembangan dan kemajuan. Dalam rangka menyiapkan generasi bangsa dalam menghadapi tantangan globalisasi ini, kualitas pendidikan di Indonesia terus mengalami pembenahan dan peningkatan di segala sisi baik dari segi kurikulum, pengajar maupun sarana dan prasarananya. 
Berkembangnya ilmu pengetahuan dan teknologi (IPTEK) yang cukup pesat merupakan salah satu ciri dari globalisasi. Dengan ilmu pengetahuan dan teknologi yang semakin berkembang ini, seharusnya guru sebagai tenaga pendidik memiliki kemampuan untuk memanfaatkannya di dunia pendidikan. Selain untuk menunjang profesinya, kecakapan guru dalam memanfaatkan kemajuan IPTEK juga bertujuan agar kegiatan pembelajaran dapat berjalan optimal dan tentunya lebih menarik. Di samping itu, pemanfaatan IPTEK dalam pedidikan ini tidak hanya bermanfaat bagi guru dan proses pembelajaran saja tetapi juga bermanfaat bagi peserta didik. Dengan mengemas pembelajaran yang menarik menggunakan kemajuan IPTEK, peserta didik akan lebih semangat dalam mengikuti proses belajar, menghilangkan kebosanan peserta didik, lebih memusatkan perhatian pada guru, serta termotivasi untuk mempelajari materi yang dijelaskan oleh guru.

Berkembangnya teknologi yang pesat ini merupakan salah satu dampak positif dari globalisasi yang sebenarnya memberikan banyak manfaat di dunia pendidikan bila dipergunakan dengan bijak dan tanggung jawab. Pemanfaatan teknologi yang ada sekarang ini dalam kegiatan belajar oleh guru akan menciptakan suasana belajar yang menyenangkan serta menghasilkan pembelajaran yang berkualitas. Peserta didik lebih dapat menyerap materi yang disampaikan oleh guru dengan baik. Pembelajaran yang berkualitas ini pun akan menghasilkan lulusan-lulusan yang handal dan berkompeten di bidangnya. Bila sumber daya manusia yang bagus ini terwujud tentu bangsa kita akan mampu bersaing dengan bangsa lain.

Dalam rangka mencetak lulusan-lulusan yang berkualitas, para pendidik atau guru harus meningkatkan kualifikasinya dalam mengajar. Kompetensi seorang guru dalam menguasai materi sangat mempengaruhi kualitas dari pembelajaran. Maka guru harus selalu aktif untuk meningkatkan kemampuannya dengan banyak membaca buku, mengikuti pelatihan atau seminar dan lain sebagainya. Guru juga dituntut untuk mampu mengakses data melalui internet, memiliki fasilitas mengajar yang memadai seperti laptop, speaker, dan lain lain serta senantiasa mengikuti perkembangan informasi dan IPTEK melalui berbagai media misalnya televisi, koran, internet, buku dan sebagainya. Di samping itu, selain dari segi kompetensi guru, metode 
atau cara yang digunakan guru dalam mengajar perlu untuk selalu ditingkatkan sehingga tercipta pembelajaran yang dinamis dan tidak stagnant. Demi menciptakan pembelajaran yang dinamis, guru dapat memberikan inovasi atau pembaruan dalam pembelajaran dengan mengembangkan kreativitasnya dalam mengajar. Dengan demikian upaya untuk menciptakan suasana belajar yang menyenangkan, menarik, namun tetap berkualitas akan tercapai.

Dalam penelitian ini, penulis menggunakan metode penelitian kualitatif deskriptif analisis yang pada umumnya menggunakan strategi multi metode yiatu wawancara, pengamatan serta study documenter yang antara satu dengan yang lain saling melengkapi, memperkuat dan menyempurnakan (sukmadinato, 2005:108) akan memaparkan beberapa inovasi pembelajaran yang dilaksanakan oleh beberapa dosen Bahasa Inggris di STAIN Kudus dalam mengajar Praktikum Bahasa Inggris. Mata kuliah ini diberikan kepada seluruh mahasiswa STAIN Kudus jurusan Tarbiyah, Ushuluddin, Syari'ah dan Dakwah pada semester-semester awal yaitu semester 1 untuk mahasiswa Syariah dan Dakwah dan semester 2 untuk mahasiswa Tarbiyah dan Ushuluddin. Bagaimana pembelajaran Praktikum Bahasa Inggris ini dikemas sedemikian rupa agar menarik bagi mahasiswa yang bukan jurusan Bahasa Inggris (non-English Department students) merupakan tugas yang berat dan menantang bagi masing-masing dosen Bahasa Inggris di STAIN Kudus. Tujuan dari penelitian ini adalah untuk mengetahui inovasi apa sajakah yang digunakan oleh dosen Bahasa Inggris STAIN Kudus dalam pembelajaran Praktikum Bahasa Inggris.

\section{B. Pembahasan}

\section{Metode Pembelajaran Inovatif}

Dalam mengajar, setiap guru menggunakan metode pembelajaran yang berbeda-beda. Metode adalah cara menyampaikan materi pelajaran dalam upaya mencapai tujuan pembelajaran (Sani, 2013: 90). Metode pembelajaran digunakan untuk menciptakan lingkungan belajar serta mendasari aktivitas guru dan peserta didik yang disusun berdasarkan prinsip dan sistem tertentu. Sedangkan inovasi adalah pembaruan atau perubahan untuk menciptakan suatu hal yang baru. Jadi, inovasi pembelajaran merupakan 
pembaruan atau perubahan yang dilakukan dalam proses belajar untuk mencapi tujuan tertentu. Bentuk-bentuk inovasi dalam pembelajaran dapat bermacam-macam antara lain: program belajar jarak jauh, pembelajaran kontekstual (contextual learning), PAKEM (Pembelajaran Aktif, Kreatif, Efektif, dan Menyenangkan), dan lainlain. Selain itu, juga terdapat berbagai macam metode pembelajaran yang banyak digunakan dalam pengajaran seperti yang telah dijabarkan oleh Sani (2013: 183) tetapi hanya akan diulas sebagian saja yaitu sebagai berikut.

\section{a. Pembelajaran Kooperatif}

Pembelajaran kooperatif ialah pembelajaran yang dilakukan secara berkelompok. Metode ini dapat dikombinasikan dengan metode yang lainnya untuk berbagai tujuan pembelajaran. Belajar secara berkelompok menguntungkan siswa karena siswa yang berkemampuan rendah bekerjasama dengan siswa yang pandai yang dapat menjadi tutor bagi temannya. Metode pembelajaran kooperatif yang umum dikenal antara lain: Numbered Heads Together (NHT); Cooperative Script; Team Assisted Individualization; Metode Belajar Bersama (Learning Together); Metode Two Stay, Two Stray; Team Accelerated Instruction; Wawancara Tiga Langkah (Three-Step Interview); dan.Cooperative Integrated Reading and Composition (CIRC).

\section{b. Pembelajaran Secara Berpasangan}

Metode ini sebenarnya merupakan pembelajaran kooperatif tetapi dibedakan pembahasannya agar mudah membedakan pembelajaran dengan kelompok besar dan pembelajaran dengan kelompok kecil (hanya 2 orang). Macam-macam dari metode ini ialah bertukar pasangan, think pair share, artikulasi, mencari pasangan, dialog berpasangan, dan pemeriksaan makalah pasangan (peer review writing task).

\section{c. Pembelajaran Individual dengan Modul}

Pembelajaran modul atau disebut juga Modular Instruction merupakan proses pembelajaran mandiri mengenai pokok bahasan tertentu dengan menggunakan bahan ajar untuk peserta didik dan para guru. Modul adalah bahan ajar berisi rangkaian kegiatan belajar yang disusun untuk peserta didik dalam mencapai sejumlah tujuan tertentu. Pembelajaran modul terdiri atas beberapa komponen, yaitu: 
1) lembar kegiatan peserta didik, 2) lembar kerja, 3) kunci lembar kerja, 4) lembar soal, 5) lembar jawaban, dan 6) kunci jawaban. Pada pembelajaran modul ini, tugas utama guru ialah menyiapka $\mathrm{n}$ kondisi pembelajaran yang kondusif, membantu peserta didik yang mengalami kesulitan, dan memantau progress belajar tiap peserta didik.

Pembelajaran dengan modul ini merupakan pembelajaran individual yang memiliki banyak keuntungan baik bagi peserta didik maupun bagi guru. Keuntungan pembelajaran modul bagi peserta didik, yaitu: (1) adanya umpan balik (feedback); (2) penguasaan tuntas (mastery); (3) tujuan belajar jelas; (4) menimbulkan motivasi belajar; (5) fleksibilitas belajar dengan menyesuaikan karakteristik perserta didik yang beragam; (6) memungkinkan kerja sama antar sesama peserta didik dan antar peserta didik dengan guru; dan (7) pengajaran remedial. Sedangkan keuntungan pembelajaran modul bagi guru antara lain guru memiliki banyak kesempatan dan waktu untuk membantu dan memperhatikan peserta didik secara individu, meningkatkan profesionalitas guru, tersedianya evaluasi yang terencana di dalam modul, dan lain-lain.

\section{d. Pembelajaran Teman Sejawat}

Pembelajaran peer tutoring atau teman sejawat yaitu metode pembelajaran dengan seorang peserta didik yang kompeten untuk mengajar peserta didik lainnya. Dalam metode ini peserta didik dituntut untuk aktif berdiskusi atau mengerjakan tugas dengan bimbingan teman yang kompeten baik di rumah maupun di sekolah. Peserta didik yang menjadi tutor dapat menjalankan berbagai peran sebagai guru, role model, pelatih, teman kerja, atau mediator tergantung pada tanggung jawab yang diberikan oleh guru. Pembelajaran teman sejawat berpusat pada peserta didik karena memberikan kesempatan belajar bagi dirinya sendiri dan orang lain. Beberapa inovasi dapat dilakukan agar pembelajaran teman sejawat menjadi menyenangkan, contohnya: mengelilingi narasumber (circle the sage) yaitu dengan guru menunjuk peserta didik yang pintar untuk menjelaskan sebuah materi dan peserta didik yang lain mengelilinya; metode fishbowl yang hampir sama dengan circle the sage dimana di akhir pembelajaran guru melakukan evaluasi untuk mengecek pemahaman peserta didik; dan juga metode belajar dengan mengajar (learning by teaching). 


\section{e. Metode Permainan}

Terdapat berbagai variasi dalam metode permainan ini maka hanya beberapa metode saja yang akan dijabarkan di bawah ini sebagai berikut.

1. Talking stick atau Talking Doll

Setelah menyampaikan materi, guru memberikan tongkat atau boneka kepada salah seorang peserta didik lalu memberikn pertanyaan. Peserta didik yang telah menjawab pertanyaan memberikan tongkat atau melemparkan boneka pada temannya, dilanjutkan dengan pertanyaan lain dari guru yang harus dijawab oleh peserta didik yang memegang tongkat/boneka itu. Kegiatan ini berlangsung sampai sebagian besar peserta didik mendapat kesempatan untuk menjawab pertanyaan. Guru membimbing peserta didik untuk membuat kesimpulan dan memberikan evaluasi pada akhir pelajaran.

2. Beach Ball

Metode ini hampir sama dengan talking stick atau talking doll. Perbedaannya terletak pada cara menyampaikan bola. Guru memberikan bola pada seorang peserta didik untuk mendiskusikan topik yang telah ditetapkan. Bila peserta didik yang lain ingin berbicara harus mengangkat tangan terlebih dahulu untuk meminta bola dan hanya boleh berbicara jika bola telah dipegangnya. Diskusi berlanjut sampai batas waktu yang telah ditentukan. Guru membimbing peserta didik untuk membuat kesimpulan dan mengevaluasi di akhir pembelajaran. Tujuan dari metode ini adalah unuk meningkatkan partisipasi peserta didik dalam berbicara dan mencegah peserta didik tertentu memonopoli pembicaraan.

3. Bola Salju (Snowball)

Peserta didik membentuk kelompok dua orang untuk mendiskusikan pertanyaan yang harus diselesaikan dari guru. Pasangan peserta didik membentuk kelompok baru terdiri dari empat orang untuk mendiskusikan jawaban yang tepat. Dua kelompok bergabung dan membentuk kelompok baru terdiri dari delapan orang lalu mendiskusikan jawaban dan ditulis pada kertas. Penggabungan kelompok dilakukan sampai semua peserta didik dalam satu kelas tergabung 
menjadi satu kelompok. Guru memantau perkembangan kelompok dan berdiskusi jawaban dengan juru bicara kelas.

4. Lempar Bola Salju (Snowball Throwing)

Metode ini berbeda dengan metode bola salju karena jumlah kelompok tidak akan terus bertambah. Guru membentuk kelompok-kelompok dan memanggil masing-masing ketua kelompok untuk menjelaskan tentang materi. Kemudian ketua kelompok kembali ke kelompok masing-masing dan menjelaskan materi dari guru kepada temannya. Masing-masing peserta didik diminta menuliskan satu pertanyaan terkait dengan materi tersebut. Kertas yang berisi pertanyaan itu dibuat seperti bola dan dilempar kepada peserta didik lain. Setelah masing-masing peserta didik memperoleh bola/pertanyaan, peserta didik tersebut diberikan kesempatan untuk menjawab pertanyaan yang ditulis dalam kertas berbentuk bola itu. Guru memberikan evaluasi di akhir pembelajaran.

5. Tari Bambu

Dalam metode ini satu kelompok peserta didik diminta berdiri berhadapan secara sejajar. Kelompok kedua berdiri berjajar menghadap kelompok pertama. Dua peserta didik saling berhadapan dan berbagi informasi. Setelah itu, salah satu jajaran bergeser ke kiri atau ke kanan sehingga masing-masing peserta didik akan memperoleh pasangan baru untuk berbagi informasi.

6. Keliling Kelompok

Metode ini hampir sama dengan metode meja bundar yaitu masing-masing kelompok duduk mengelilingi meja. Masing-masing anggota kelompok menyediakan pulpen selembar kertas untuk menulis jawaban atau respon terhadap pertanyaan yang diajukan oleh guru melalui ketua kelompok secara bergantian dan harus berhenti menulis bila waktu yang ditentukan telah habis.

\section{Teknik Pembelajaran Bahasa}

Teknik merupakan usaha, daya upaya, atau cara yang digunakan guru dalam mencapai tujuan langsung pada pelaksanaan pembelajaran saat itu (Sani, 2013: 279). Dalam pengajaran bahasa 
banyak dikenal bermacam-macam teknik seperti permainan, diskusi, role play atau bermain peran, dikusi, dan lain-lain. Salah satu teknik yang banyak digunakan dalam pengajaran bahasa adalah permainan. Selain dapat menciptakan suasana yang relaxed dan enjoyable, pengajaran dengan permainan juga dapat memotivasi peserta didik untuk mengikuti kegiatan belajar dengan sungguh-sungguh. Bila guru menggunakan teknik pembelajaran yang tepat dalam pembelajaran bahasa maka peserta didik akan mudah memahami bahasa yang sedang dipelajarinya.

Beberapa teknik pembelajaran yang dapat digunakan untuk melatih beberapa keterampilan berbahasa peserta didik diantaranya membaca, mendengarkan, dan berbicara menurut Sani (2013: 281) ialah:

\section{a. Teknik percakapan singkat}

Teknik ini bertujuan untuk melatih peserta didik berbicara secara bebas dan untuk mengembangkan kemampuannya dalam mempelajari bahasa asing. Percakapan dilakukan secara berkelompok dengan memilih sebuah topik. Guru mencatat kesalahan atau kesulitan yang dialami peserta didik. Setelah selesai percakapan, guru menjelaskan tentang frasa atau kalimat yang perlu diperbaiki.

\section{b. Teknik cerita berangkai}

Kegiatan yang dilakukan oleh peserta didik adalah melanjutkan cerita yang disampaikan oleh temannya dengan tepat. Satu kelompok dapat terdiri dari lima sampai enam orang. Kelompok ini berdiri di depan kelas dan bercerita tentang topik tertentu diawali dari kanan ke kiri atau dari kiri ke kanan. Teknik ini juga dapat digunakan untuk belajar bahasa Inggris dalam mempelajari conditional sentence. Pertama, guru menjelaskan tentang conditional sentence tipe 1. Peserta didik secara berkelompok diminta untuk membuat kalimat menggunakan "if" dan "will”, dimulai dari satu orang dan disambung secara berantai oleh teman yang lain.

Contoh:

Peserta didik 1 If I were rich, I will buy a car.

Peserta didik 2 If I have a car, I will go around the city. 
Peserta didik 3 If I go around the city, I will take my friends.

\section{c. Teknik mendengarkan berantai}

Teknik ini melatih keterampilan peserta didik dalam mendengarkan (menyimak). Pelaksanaan dari teknik ini ialah peserta didik menyampaikan informasi yang didengar kepada teman lain di belakang atau di sebelahnya secara berantai dalam kelompok. Peserta didik yang paling belakang mengucapkan dengan keras informasi yang didengar dari temannya. Peserta didik yang terdepan mencocokkan apa yang diucapkan oleh peserta terakhir dengan informasi yang asli. Kegiatan tersebut dapat diulangi lagi dengan informasi yang berbeda. Tujuan dari teknik ini adalah peserta didik dapat memahami informasi yang dibisikkan oleh temannya dengan cepat dan tepat.

\section{d. Teknik mendengarkan cerita}

Pembelajaran dengan teknik ini dapat dilakukan secara perseorangan maupun kelompok. Guru menyediakan kaset cerita dan tape recorder untuk mendengarkan cerita. Peserta didik diminta untuk mendengarkan cerita yang diputar dengan seksama. Lalu, peserta didik diminta untuk mengidentifikasi cerita tersebut berdasarkan tokoh, tempat, waktu dan tentang apa, bagaimana, mengapa ataupun makna dari cerita tersebut. Peserta didik memberikan melaporkan hasil diskusi di depan kelas dan kelompok lain memberikan pendapat atau penilaian. Tujuan dari teknik ini adalah peserta didik dapat memaknai cerita yang didengar dengan cermat, cepat dan tepat.

\section{e. Teknik percakapan dengan bertanya}

Peserta didik pertama mengajukan pertanyaan kepada peserta didik kedua. Kemudian peserta didik kedua juga mengajukan pertanyaan terkait dengan pertanyaan peserta didik pertama.

Contoh:

Peserta 1: Apakah kamu pergi ke sekolah hari ini? 
Peserta 2: Apakah menurut kamu sekolah tidak libur hari ini?

Peserta1: Mengapa kamu berpikir bahwa sekolah libur hari ini?

Peserta 2: Apakah kamu tidak mendengarkan penjelasan guru kemarin di sekolah?

Peserta 1: Apa yang dijelaskan oleh guru kemarin di sekolah?

Teknik ini bertujuan untuk meningkatkan kemampuan peserta didik dalam membuat pertanyaan dan juga mengembangkan kemampuan berkomunikasi.

\section{f. Teknik menerangakan benda}

Pada teknik ini peserta didik disuruh untuk menerangakan karakter sebuah benda yang sudah dikenal dalam waktu singkat. Benda tersebut dapat berupa bendabenda di sekeliling mereka seperti tas, sepatu, makanan, dan lain-lain. Kegiatan ini dilakukan secara berkelompok dengan membawa benda yang mereka jelaskan. Peserta didik secara bergantian menerangkan karakteristik benda yang mereka bawa dalam waktu tertentu, lalu peserta didik lainnya memberikan komentar atau tambahan informasi dari penjelasan temannya. Tujuan dari teknik ini adalah peserta didik dapat menjelaskan suatu benda secara runtut dan benar.

\section{g. Teknik bermain peran}

Teknik bermain peran ini dapat dilakukan dengan dua cara. Pertama, kegiatan ini dapat dilakukan secara perseorangan yaitu dengan peserta didik menirukan gaya tokoh yang diidentifikasi dengan ucapan yang mirip atau sama. Peserta didik yang lain menuliskan komentar atas peran yang dimainkan temannya pada selembar kertas folio. Kedua, selain dapat dilakukan perseorangan teknik ini juga dapat dilakukan lebih dari satu orang yaitu berpasangan atau berkelompok. Guru menginstruksikan kepada peserta didik untuk melakukan peran tertentu untuk penyelesaian tugas tertentu. Contoh kegiatannya adalah mempraktekkan percakapan antara penjual dan pembeli yang menuntut 
penggunaan ungkapan-ungkapan pada situasi tertentu. Peserta didik tidak menghafalkan percakapan tersebut tetapi mereka membuat kalimat secara langsung berdasarkan situasi yang mereka praktekkan. Permain peran ini bertujuan untuk melatih berbicara secara alami sesuai dengan situasi yang mereka hadapi yang membutuhkan ungkapan-ungkapan dengan berbagai macam fungsi.

\section{Metode Pembelajaran Bahasa Asing}

Seperti yang telah dijelaskan sebelumnya bahwa terdapat berbagai macam metode yang digunakan oleh guru dalam mengajar. Pada pembahasan berikut ini, metode pembelajaran akan dibahas lebih khusus lagi yaitu metode yang digunakan dalam pembelajaran bahasa asing. Terdapat tujuh metode pembelajaran bahasa asing yang dijabarkan oleh Sani (2013: 292) yang hanya akan diulas beberapa diantaranya saja sebagai berikut.

\section{a. Pembelajaran Berbasis Teks}

Pembelajaran bahasa asing yang sering digunakan saat ini adalah pembelajaran berbasis teks. Jenis teks yang umumnya digunakan ialah: recount text, descriptive text, report text, dan explanation text. Penggunaan teks-teks ini berbedabeda menurut fungsi masing-masing teks. Recount text digunakan untuk menceritakan kejadian atau pengalaman di waktu lampau. Descriptive text digunakan untuk mendeskripsikan benda, orang, ataupun tempat. Report text berfungsi untuk memberikan informasi/melaporkan suatu peristiwa setelah diadakan investigasi. Tujuan dari metode ini adalah agar peserta didik mampu menyusun teks dengan baik dan benar serta melatih keterampilan menulis (writing skill).

\section{b. Metode Terjemahan dan Tata Bahasa}

Metode ini bertujuan untuk melatih kemampuan menulis, membaca, dan menerjemahkan. Kegiatan dari metode ini terlebih dahulu memerlukan bimbingan dari guru. Guru menerjemahkan kata-kata baru/sulit dan peserta didik diminta untuk menghafalkan. Kemudian, guru membaca teks tersebut kalimat per kalimat dan peserta didik diminta untuk menerjemahkan. Guru juga harus menjelaskan kaidah-kaidah 
tata bahasa dari teks tersebut sehingga peserta didik dapat menerjemahkan teks secara bebas.

\section{c. Metode Langsung (Direct Method)}

Tujuan dari metode ini ialah peserta didik dapat menguasai dan mengembangkan bahasa yaitu berhubungan langsung dengan pengalaman dan ekspresi seara lisan. Metode ini juga digunakan agar peserta didik mampu berpikir dengan bahasa sasaran dalam percakapan, menulis, dan membaca. Pembelajaran menggunakan bahasa sasaran sebagai pengantar secara lisan dengan dimulai mengajarkan kata-kata atau ungkapan-ungkapan yang menggunakan indera atau perbuatan yang diperagakan. Pembelajaran dihubungkan dengan penggunaan bahasa pada percakapan atau ucapan sehari-hari.

\section{d. Metode Membaca}

Metodemembacainibertujuanuntukmengembangkan kemampuan peserta didik dalam membaca serta memahami bahasa asing dengan lebih mudah. Pencapaian tujuan pembelajaran ini dengan cara membiasakan membaca tanpa menerjemahkan atau menganalisis teks. Selanjutanya peserta didik dilatih untuk membaca cepat dalam hati. Metode ini memiliki kelebihan dan kekurangan, yaitu memberikan kesempatan pada peerta didik untuk memperoleh sendiri kompetensi berbahasa sesuai dengan kemampuannya tetapi peserta didik kurang memiliki keterampilan dalam menyimak dan berbicara.

\section{e. Metode Audio Lingual}

Metode ini digunakan untuk meningkatkan empat keterampilan berbahasa peserta didik yaitu menyimak, berbicara, menulis, dan membaca. Dalam kegiatan belajar mengajar umumnya menggunakan pendekatan oral approach yaitu menggunakan latihan pola atau meniru dan mengingat. Peserta didik diminta untuk meniru, mengingat, atau menghafalkan materi yang telah diperoleh yang diberikan secara bertahap mulai yang mudah sampai yang sulit. 


\section{Pengembangan Kreativitas Pembelajaran Guru}

Sebelum mengajar, sebaiknya guru perlu membuat konsep terlebih dahulu mengenai pembelajaran seperti apa yang akan diberikan serta bagaimana menciptakan atmosfer belajar yang menyenangkan agar menarik perhatian dan memberikan motivasi belajar pada peserta didik. Pembelajaran yang tidak menarik dan menumbuhkan motivasi peserta didik cenderung monoton, kaku, dan membosankan. Proses penyampaian materi juga menjadi tidak maksimal dan akan berpengaruh pada hasil belajar peserta didik. Oleh karena itu diperlukan kreativitas dari seorang guru untuk mengkonsep pembelajaran yang menyenangkan.

Kreativitas dibagi ke dalam dua segi yaitu: kreativitas dalam proses pembelajaran dan kreativitas perwujudan perilaku guru. Agung (2010: 38) menjelaskan bahwa kreativitas tidak hanya mengacu pada hal-hal yang berhubungan dengan proses pembelajaran saja tetapi juga perwujudan perilaku guru itu sendiri. Kreativitas pada perwujudan perilaku guru maksudnya adalah pembawaan guru yang komunikatif, luwes, membimbing, menyenangkan dalam mengajar. Kreativitas ini dapat diwujudkan dengan berbagai cara antara lain: menggunakan gaya bahasa yang komunikatif dan tidak monoton, menciptakan interaksi belajar mengajar yang luwes dan bersahabat dengan peserta didik, memberikan pujian terhadap peserta didik yang memperhatikan dan memiliki motivasi belajar, dan sebagainya.

Sedangkan kreativitas dalam proses pembelajaran berhubungan dengan pemberian materi pelajaran, metode yang digunakan, dan lain-lain. Dalam kreativitas ini, guru dituntut untuk melakukan persiapan mengajar. Perwujudan dari kreativitas ini dapat berupa: menentukan dan memilah materi/bahan ajar yang akan diberikan pada peserta didik, merancang cara untuk menimbulkan keaktifan dalam pembelajaran seperti diskusi, simulasi, dan lainlain. Pengelolaan kelas dan pemanfaatan waktu juga menjadi bahan pertimbangan bagi guru. Di samping itu, guru juga harus merancang metode pembelajaran dan media pembelajaran yang akan digunakan. Satu hal yang juga tidak kalah penting ialah merancang bentuk/jenis tes sebagai alat evaluasi hasil belajar siswa serta menentukan waktu pelaksanaan evaluasinya.

Dalam mengembangkan kreativitas pembelajaran guru, 
terdapat beberapa strategi yang dapat dilaksanakan oleh guru seperti yang disebutkan oleh Agung (2010:68) berikut ini:

1. Memperluas wawasan dan pengetahuan: semakin luas pengetahuan seorang guru, semakin kreatif dalam penyampaian gagasan/ide sehingga tidak monoton.

2. Mengembangkan lingkungan fisik pembelajaran: ruang belajar yang indah, bersih, tenang, terang, nyaman dan rapi akan menciptakan iklim belajar yang kondusif.

3. Mengembangkan sikap keterbukaan: guru harus membuka diri terhadap pendapat atau kritik dari pihak lain termasuk peserta didik sebagai refleksi dan introspeksi.

4. Mengembangkan komunitas kelas: guru perlu menciptakan suasana kelas yang kondusif, nyaman, mengasyikkan, penuh keakraban dengan peserta didik.

5. Memunculkan tantangan dan mengembangkan alat evaluasi: guru memiliki kemampuan untuk memunculkan tantangan pada peserta didik untuk menyelesaikan suatu masalah.

6. Optimalisasi pemanfaatan teknologi pembelajaran: guru memiliki kemampuan dalam memanfaatkan media pembelajaran yang akan menarik minat peserta didik.

\section{Inovasi Pembelajaran Praktikum Bahasa Inggris di STAIN Kudus}

Praktikum Bahasa Inggris merupakan salah satu mata kuliah perilaku berkarya (MPB) di STAIN Kudus yang diberikan secara bersamaan dengan Bahasa Inggris I dan Bahasa Inggris II dalam satu semester. Masing-masing mata kuliah ini memiliki fungsi tersendiri yaitu Bahasa Inggris I lebih memfokuskan pada penguasaan structure dan grammar (writing skill) sedangkan Bahasa Inggris II fokus pada reading comprehension yaitu kemampuan untuk memahami teks-teks Bahasa Inggris khususnya yang berhubungan dengan Islam (reading skill). Praktikum Bahasa Inggris, sesuai dengan namanya, mata kuliah ini memfokuskan pada praktik yaitu mempraktikkan semua keterampilan berbahasa yang terdiri dari listening skill, speaking skill, writing skill, dan reading skill dalam satu mata kuliah. Pemberian semua keterampilan berbahasa ini juga dimaksudkan untuk membekali peserta didik agar siap untuk mengikuti latihan test TOEFL yang diselenggarakan oleh Unit Pengembangan Bahasa STAIN Kudus 
pada setiap akhir semester.

Dalam mengajar praktikum Bahasa Inggris, masing-masing dosen Bahasa Inggris di STAIN Kudus menggunakan metode yang berbeda-beda. Dosen-dosen tersebut pun juga melakukan inovasi dalam pembelajaran praktikum Bahasa Inggris. Hal ini dimaksudkan agar proses belajar tidak monoton serta lebih menarik dan menyenangkan sebab tidak mudah untuk mengajarkan Bahasa Inggris kepada peserta didik kurang tertarik dengan Bahasa Inggris terlebih lagi mata kuliah ini bukan mata kuliah inti dari keilmuan masingmasing program studi. Maka pembelajaran praktikum Bahasa Inggris haruslah dikemas sedemikian rupa supaya menarik, menyenangkan, dan memotivasi peserta didik untuk mau belajar Bahasa Inggris. Di samping itu, alasan lain dengan diadakannya inovasi dan pemilihan metode yang berbeda ini adalah didasarkan pada kompetensi yang dimiliki oleh pesera didik dan kebutuhan yang diperlukan peserta didik. Kompetensi peserta didik pada satu kelas dengan kelas yang lainnya tentu berbeda dan memerlukan treatment yang berbeda pula. Di sinilah penerapan inovasi dan pilihan metode yang sesuai diperlukan agar pembelajaran berjalan dengan optimal.

Beberapa inovasi pembelajaran praktikum Bahasa Inggris yang dilaksanakan oleh beberapa dosen Bahasa Inggris di STAIN Kudus di antaranya adalah:

\section{a. Pembelajaran Audio Visual}

Pada pembelajaran ini dosen menggunakan beberapa media dalam kegiatan belajar. Media-media yang digunakan yaitu diantaranya laptop, audio (speaker), dan proyektor. Pelaksanaan dari pembelajaran ini adalah dosen memutarkan video percakapan native speaker Bahasa Inggris yang berkaitan dengan materi yang terdapat dalam modul Praktikum Bahasa Inggris. Materi-materi yang terdapat di dalam modul itu antara lain:

1. Greeting, introducing people, and farewell

2. Describing people

3. Cities, locations, directions, and building

4. Asking for, giving opinions, suggestions

5. Request and apologies

6. Talking about the past 
Pelaksanaan pembelajaran audio visual ini dijabarkan secara rinci ke dalam langkah-langkah sebagai berikut.

1. Dosen menyiapkan terlebih dahulu video-video percakapan yang berkaitan dengan materi-materi tersebut.

2. Dosen membagi mahasiswa ke dalam beberapa kelompok.

3. Dosen memutarkan video tersebut kepada mahasiswa di dalam kelas. Satu kali pertemuan hanya membahas satu materi saja. Satu materi tersebut dapat diulas dengan satu atau dua video percakapan.

4. Dosen meminta mahasiswa utuk menyimak video percakapan tersebut dengan materi yang telah ditentukan.

5. Setelah selesai menyimak, tiap kelompok diminta untuk membuat percakapan dengan tema/materi yang serupa dengan menggunakan bahasa mereka sendiri.

6. Tiap kelompok bergiliran mempraktikkan percakapan yang telah mereka buat di depan kelas.

7. Praktik percakapan tersebut dapat diulang yang kedua kalinya tanpa menggunakan teks percakapan.

8. Dosen memberikan koreksi atau pembetulan atas pengucapan, struktur kalimat, atau bentuk tenses yang kurang tepat di akhir percakapan.

Pembelajaran audio visual ini bertujuan untuk menumbuhkan kreativitas mahasiswa dalam membuat percakapan yang berhubungan dengan situasi sehari-hari dengan tema yang telah ditentukan oleh dosen. Di samping itu, pembelajaran ini juga bermanfaat untuk membiasakan mahasiswa bercakap-cakap menggunakan Bahasa Inggris dengan pronunciation yang baik dan benar melalui video percakapan native speaker.

\section{b. Pembelajaran Constructing Sentences}

Pembelajaran ini bertujuan untuk melatih mahasiswa menyusun kalimat-kalimat dalam Bahasa Inggris dengan menggunakan bentuk tenses dan structure yang benar. Pembelajaran constructing sentences ini dipilih karena mata kuliah Praktikum Bahasa Inggris menuntut mahasiswa dapat mempraktikkan semua keterampilan berbahasa termasuk writing skill. Agar mahasiswa mahir dalam keterampilan menulis, pengetahuan tentang bentuk-bentuk tenses haruslah dimiliki. Materi tentang bentuk tenses biasanya sangat 
membosankan bagi mahasiswa maka pembelajaran ini dikemas sedikit berbeda oleh dosen agar menumbuhkan motivasi mahasiswa dalam belajar bentuk tenses.

Tahapan penerapan pembelajaran constructing sentences diuraikan secara rinci sebagai berikut.

1. Dosen menerangkan tentang bentuk tenses tertentu secara singkat tetapi lengkap dengan pattern atau polanya.

2. Dosen membagi mahasiswa ke dalam sejumlah kelompok terdiri dari lima orang.

3. Pada permulaan dosen menentukan tenses dan parts of speech yang akan dipelajari. Misalnya parts of speech yang akan dibahas adalah noun dan tenses nya adalah Simple Present Tense.

4. Dosen meminta mahasiswa untuk duduk melingkar dengan kelompok masing-masing. Tiap kelompok dituntut untuk praktik membuat kalimat secara lisan berdasarkan tenses yang telah dijelaskan dosen.

5. Praktik dimulai dari orang pertama dari kelompok pertama diminta untuk menyebutkan satu noun.

6. Orang kedua harus membuat kalimat menggunakan noun yang telah disebutkan oleh orang pertama dengan bentuk tenses Simple Present Tense.

7. Orang ketiga diminta membuat negative sentence dari kalimat tersebut.

8. Orang keempat membuat interrogative sentence dari kalimat tersebut.

9. Orang kelima bertugas menjawab pertanyaan dari orang keempat.

10. Kelompok kedua dan lainnya yang memilih noun sama dengan kelompok pertama harus mengganti dengan noun yang berbeda.

11. Dosen memberikan koreksi atau pembetulan atas pengucapan, struktur kalimat, atau bentuk tenses yang kurang tepat di setiap kelompok.

Contoh:

Orang $1:$ student

Orang 2 : We are students. 
Orang 3 : We are not students.

Orang 4 : Are we students?

Orang 5 : Yes, we are. / No, we aren't.

Setelah semua kelompok selesai mempraktikkan kalimatnya masing-masing, dosen dapat melanjutkan pembelajaran constructing sentences ini dengan tetap menggunakan bentuk tenses yang sama tetapi mengganti parts of speech-nya yaitu adjective, adverb, dan lain-lain. Selanjutnya, pembelajaran dapat dilanjutkan lagi dengan mengganti bentuk tenses-nya sesudah dosen menerangkan tentang bentuk tenses yang baru.

\section{c. Pembelajaran Direct Practice}

Pada permulaan pembelajaran atau di awal pertemuan, dosen memberikan small test atau semacam pre-test kepada mahasiswa yang dapat berbentuk written atau oral test untuk mengetahui sejauh mana kemampuan atau kompetensi dari para mahasiswa di kelas tersebut. Pre-test semacam ini perlu dilakukan karena untuk menentukan metode atau teknik apa yang akan digunakan oleh dosen dalam pembelajaran nantinya. Pre-test dilakukan tidak secara formal dan tidak terlalu sulit melainkan hanya sederhana saja seperti meminta mahasiswa untuk mengucapkan beberapa kata dalam Bahasa Inggris (how to pronounce), spelling, menjelaskan grammar/structure dalam Bahasa Inggris, dan lain-lain. Setelah dosen melakukan pre-test tersebut, diketahui bahwa kemampuan para mahasiwa masih sangat rendah. Dalam kondisi seperti ini, communicative approach tentu kurang tepat diaplikasikan dalam pembelajaran. Oleh sebab itu, dosen dituntut untuk dapat mendesain sendiri metode yang akan digunakan dalam pembelajaran di kelas yang mayoritas mahasiswanya memiliki low competence. Metode yang digunakan pada kelas satu dengan yang lainnya tentu akan berbeda karena disesuaikan dengan kemampuan dari mahasiswa di tiap-tiap kelas berdasarkan hasil pre-test di awal pertemuan.

Pembelajaran Direct Practice ini didesain oleh salah seorang dosen Bahasa Inggris di STAIN Kudus karena mengalami kendala dalam mengajar Praktikum Bahasa Inggris. Pembelajaran ini khususnya diaplikasikan pada kelas yang mayoritas mahasiswanya berkemampuan rendah dalam Bahasa Inggris karena pada dasarnya pembelajaran ini sangat simple dan mudah sehingga kurang cocok 
diterapkan pada mahasiswa yang memiliki kompetensi baik dalam Bahasa Inggris. Penerapan pembelajaran direct practice ini akan dijabarkan secara rinci sebagai berikut.

1. Dosen bersama-sama mahasiswa membuat words list (daftar kata) dalam Bahasa Inggris dan artinya sejumlah 40 kata setiap pertemuan dalam parts of speech tertentu.

Contoh:

$1^{\text {st }}$ meeting - 40 Nouns (inside the class)

Chair kursi

Table meja

Window jendela

Door pintu

etc.

2. Dosen meminta mahasiswa untuk melafalkan kata-kata tersebut dengan pengucapan yang benar dan menghafalkannya beserta artinya. Pada pertemuan selanjutnya mahasiswa harus mempraktikkannya di depan kelas.

3. Pada pertemuan kedua, dosen memanggil 5 anak untuk berdiri di depan kelas dan mempraktekkan hafalannya.

4. Salah satu mahasiswa yang lain bertugas untuk menyebutkan satu per satu 40 nouns dalam Bahasa Indonesia sedangkan 5 mahasiswa di depan kelas menjawabnya dalam Bahasa Inggris secara serempak. Bila ada mahasiswa yang diam saja karena lupa atau belum hafal, dia harus mengulangi hafalannya lagi minggu depan.

5. Di pertemuan selanjutnya, dosen bersama mahasiswa menyusun kembali 40 daftar kata untuk adjectives dan memberikan instruksi yang sama kepada mahasiswa seperti sebelumnya.

6. Pertemuan berikutnya dapat dilanjutkan dengan pemberian 40 verbs, 40 nouns outside the class (animals, vegetables, fruits), etc.

7. Setelah mahasiswa dapat menghafalkan sejumlah kata dengan bermacam-macam parts of speech, dosen melatih mereka untuk merangkai atau menyusun jenis kata yang satu dengan yang lain membentuk frasa misalkan adjective dirangkai dengan noun atau verb dengan noun. 
Contoh:

$\begin{array}{ll}\frac{\text { adjective }+ \text { noun }}{\text { pronoun }+ \text { verb }} & \text { verb }+ \text { noun } \\ \text { redflower } & \text { eat mango } \\ \text { beautiful woman } & \text { sheworks } \\ & \text { drink coffee } \\ \text { long ruler } & \text { study English } \\ & \text { they play, etc. }\end{array}$

8. Ketika mahasiswa telah mahir dalam merangkai kata menjadi frasa, dosen mengajarkan cara membuat kalimat baik itu kalimat nominal maupun verbal. Pada mulanya kalimat yang diajarkan sangat sederhana dengan menggunakan demonstrative pronoun dan Simple Present Tense.

\section{Contoh:}

This is a book.

That is a lamp. things inside the class

Those are windows.

Mahasiswa mengucapkan kalimat-kalimat tersebut sambil menunjuk ke arah benda-benda yang disebutkan. Hal ini bertujuan supaya mahasiswa dapat membedakan penggunaan kata tunjuk untuk benda yang dekat dan jauh ataupun benda yang jamak atau tunggal.

9. Kemudian dosen melemparkan sebuah bola kepada mahasiswa secara acak. Mahasiswa yang memperoleh bola itu harus maju ke depan kelas untuk mendemonstrasikan gerakan dengan membawa sebuah benda.

Contoh:

Seorang mahasiswa maju ke depan kelas membawa buku. Teman-temannya yang lain diminta untuk membuat kalimat. This is a book.

Mahasiswa itu kemudian menjauhkan bukunya dan menunjuknya. Lalu teman-teman yang lain mengatakan:

That is a book.

Mahasiswa mengambil kembali bukunya dan membawa buku yang lain. Teman-temannya membuat kalimat sebagai berikut. These are books. 
Mahasiswa yang menjadi peraga tersebut harus mampu untuk menilai apakah kalimat yang diucapkan oleh temantemannya sduah betul atau belum. Kemudian pembelajaran dapat dilanjutkan kembali dengan melempar bola kembali dan meminta mahasiswa untuk membawa benda yang lain ke depan kelas.

10. Pertemuan-pertemuan selanjutnya dosen dapat mengajarkan kalimat verbal dalam Simple Present Tense, Simple Past Tense dan Simple Future Tense beserta polanya dalam kalimat positif, negatif, dan tanya.

11. Setelah 3 tenses tersebut dipahami, dosen meminta mereka untuk membuat masing-masing sebuah kalimat dari 3 tenses tersebut. Kemudian kertas itu ditukarkan pada teman di sampingnya. Dosen kembali menunjuk seorang diantara mahasiswa untuk berdiri di depan kelas. Dosen meminta mahasiswa A itu untuk mengatakan kalimat yang telah ia buat.

Contoh:

I go to school.

Lalu dosen melambaikan kedua tangannya yang berarti mahasiswa A harus mengubah kalimatnya menjadi negatif.

I don't go to school.

Bila dosen membuka kedua tangannya, ia harus mengubahnya menjadi kalimat tanya.

Do I go to school?

Bila dosen mengarahkan kedua tangannya ke belakang punggung, berarti dia harus mengubahnya menjadi kalimat Simple Past Tense. Bila dosen merentangkan kedua tangannya ke depan, dia harus mengubahnya menjadi Simple Future Tense dan seterusnya. Teman yang duduk di sampingnya bertugas untuk mengoreksi kalimat yang sebelumnya telah dibuat oleh mahasiswa A.

12. Pada pertemuan-pertemuan tertentu dosen juga menggunakan modul praktikum Bahasa Inggris untuk mengajarkan materi Introduction, Greetings, dan lain-lain kepada mahasiswa. Kemudian meminta mereka untuk mempraktikkannya di depan kelas dengan grupnya.

13. Setelah itu dosen memberikan tugas atau homework berupa 
membuat percakapan yang berisi greetings, introduction, dan parting secara kelompok untuk dipraktikkan pada pertemuan berikutnya.

Tujuan dari pembelajaran direct practice ini adalah untuk mengajarkan Bahasa Inggris dari awal yang paling sederhana kepada mahasiswa yang memiliki kemampuan rendah. Di samping itu, pembelajaran ini juga melatih mahasiswa untuk terbiasa berbahasa Inggris dengan meminta mereka praktik secara langsung satu per satu.

\section{d. Pembelajaran melalui lagu}

Pembelajaran Praktikum Bahasa Inggris dengan menggunakan lagu ini dapat bermacam-macam bentuknya menurut kreativitas masing-masing dosen. Berikut ini akan dijabarkan beberapa pembelajaran Bahasa Inggris melalui lagu yang dilaksanakan oleh beberapa dosen Bahasa Inggris di STAIN Kudus.

1. Listening English Song and Filling the Missing Lyrics

Pembelajaran melalui lagu yang pertama ialah mendengarkan dan mengisi lirik yang hilang. Pembelajaran seperti ini sering digunakan oleh guru di SMP maupun SMA dan juga oleh dosen di perguruan tinggi. Tata cara dalam pembelajaran ini ialah sebagai berikut.

a) Dosen menyiapkan beberapa lembar lirik lagu Bahasa Inggris yang rumpang untuk dibagikan kepada mahasiswa.

b) Dosen akan memutarkan sebuah lagu Bahasa Inggris sampai selesai. Tugas mahasiswa adalah menyimak lirik lagu tersebut, lalu mencocokkannya dengan lirik yang telah mereka terima, dan mengisi beberapa kata lirik yang hilang berdasarkan yang mereka dengar.

c) Bilasampailagu habis mahasiswa belumbisamenyelesaikan tugasnya, dosen dapat memutar kembali lagu tersebut satu kali lagi.

d) Di akhir pembelajaran, dosen dan mahasiswa bersamasama mencari kata apa saja yang hilang dari lirik tersebut dan mencocokkan dengan lagunya. Para mahasiswa mengoreksi pekerjaan mereka dan membetulkannya jika ada yang salah. 
Pembelajaran ini betujuan untuk mengasah listening skill dari mahasiswa, kepekaan mereka terhadap ucapan-ucapan Bahasa Inggris, serta pengetahuan mereka tentang penulisan kata-kata yang benar dalam Bahasa Inggris.

2. Singing English Song

Pembelajaran Praktik bahasa Inggris akan lebih menyenangkan bila disisipi dengan nyanyian sehingga akan menciptakan suasana yang riang dan menghilangkan kejenuhan. Pada awal pembelajaran peserta didik dikenalkan dengan lagu Bahasa Inggris yang mudah dahulu, tidak terlalu sulit, dan sifatnya menghibur serta mengajak. Karena awal pembelajaran maka lebih tepat dipilih nyanyian yang berisi agenda apa yang akan kita lakukan dalam belajar Bahasa Inggris. Lagu "I want to study English" ini diperoleh dosen STAIN Kudus dari sebuah pelatihan yang diselenggarakan oleh Unit Pengembangan Bahasa (UPB) STAIN Kudus. Lalu, lagu ini digunakan oleh para dosen Bahasa Inggris dalam mengajar Praktikum Bahasa Inggris. Lirik dari lagu tersebut adalah sebagai berikut.

\title{
"I want to study English"
}

\author{
I want to study English (clap 3x) \\ I want to study English (clap 3x) \\ I want to study... \\ I want to study... \\ I want to study English (clap 3x) \\ I want to listen to English (clap 3x) \\ I want to speak in English (clap 3x) \\ I want to write English \\ I want to read English \\ I want to study English (clap 3x)
}

Source: Suparyana-BBC Semarang

Pada pertemuan selanjutnya, dosen memberikan lagu Bahasa Inggris yang lain yaitu sedikit lebih sulit dari lagu sebelumnya. Lagu ini diperoleh dari seorang mahasiswa kelas PGMI-C angkatan 
2014 pada mata kuliah Bahasa Inggris II (Reading). Mahasiswa itu memberikan lagu ini di akhir presentasinya pada mata kuliah tersebut sebagai ice breaking supaya teman-temannya lebih enjoy dalam mengikuti mata kuliah Bahasa Inggris. Lagu ini kemudian digunakan oleh dosen dalam mengajar Bahasa Inggris I maupun Praktik Bahasa Inggris sebab lagu ini berisi pola semua jenis tenses yaitu 16 tenses. Lagu tersebut dinamakan Tenses Song yang liriknya sebagai berikut.

Tenses Song

(Anonymous)

I sing a song

I am singing a song

I have sung a song

I have been singing a song

I sang a song

I was singing a song

I had sung a song

I had been singing a song

I will sing a song

I will be singing a song

I will have sung a song

I'll have been singing a song

I would sing a song

I would be singing a song

I would have sung a song

I'd have been singing a song

My tenses......

Source: Ryan (PGMI-C)

Setelah mahasiswa diajarkan menyanyi lagu tersebut, dosen meminta mereka untuk membuat polanya. Pada awalnya dosen membimbing mereka untuk menganalisis tenses apa yang digunakan tiap kalimat dalam liriknya. Kemudian mahasiswa diminta untuk secara mandiri mencari rumus atau pola dari masing-masing jenis tenses. Dosen menyiapkan lembar kerja seperti di bawah ini. 


\begin{tabular}{ll}
\hline \multicolumn{1}{c}{ Lyrics } & \multicolumn{1}{c}{ Tenses } \\
\hline I sing a song & Simple Present Tense \\
\hline I am singing a song & Present Continuous Tense \\
\hline I have sung a song & Present Perfect Tense \\
\hline I have been singing a song & $\begin{array}{l}\text { Present Perfect } \\
\text { Continuous }\end{array}$ \\
\hline
\end{tabular}

\begin{tabular}{ll}
\hline I sang a song & Simple Past Tense \\
\hline I was singing a song & Past Continuous Tense \\
\hline I had sung a song & Past Perfect Tense \\
\hline I had been singing a song & Past Perfect Continuous \\
\hline
\end{tabular}

\begin{tabular}{ll}
\hline I will sing a song & Simple Future Tense \\
\hline I will be singing a song & Future Continuous Tense \\
\hline I will have sung a song & Future Perfect Tense \\
\hline $\begin{array}{l}\text { I'll have been singing a } \\
\text { song }\end{array}$ & Future Perfect Continuous \\
\hline
\end{tabular}

\begin{tabular}{ll}
\hline I would sing a song & Simple Past Future \\
\hline I would be singing a song & Past Future Continuous \\
\hline I would have sung a song & Past Future Perfect \\
\hline I'd have been singing a & $\begin{array}{l}\text { Past Future Perfect } \\
\text { song }\end{array}$ \\
\hline
\end{tabular}

My Tenses.....

Di akhir pembelajaran, dosen mengevaluasi hasil kerja mahasiswa dan mendiskusikannya bersama-sama serta memberikan koreksi. Dengan demikian, mahasiswa tidak akan merasa jenuh untuk belajar jenis tenses karena dikemas secara menarik dengan lagu. Di samping itu, manfaat lain dari pembelajaran ini adalah mahasiswa lebih mudah dalam menghafalkan pola tiap-tiap tenses yaitu hanya cukup dengan menghafal lirik dan menyanyikannya saja tanpa harus susah dan rumit menghafalkan rumus masing-masing tenses.

\section{Simpulan}

Dosen Bahasa Inggris di STAIN Kudus menggunakan cara 
atau metode yang berbeda-beda dalam mengajar Praktikum Bahasa Inggris. Hal ini dipengaruhi oleh beberapa faktor yaitu berbedanya daya kreativitas masing-masing dosen, sarana atau fasilitas yang dimiliki oleh dosen atau kampus, dan yang lebih utama ialah berbedanya kompetensi dari mahasiswa tiap-tiap kelas, prodi atau jurusan. Sehingga metode yang dipilih pun harus disesuaikan dengan kemampuan dari mahasiswa masing-masing kelas/prodi/jurusan. Bahkan, banyak dosen yang melakukan inovasi dalam pembelajaran Praktikum Bahasa Inggris dengan mendesain metode sendiri, meningkatkan kreativitas dalam pembelajaran, dan sebagainya. Inovasi pembelajaran ini dimaksudkan untuk mewujudkan pembelajaran yang aktif, kreatif, efektif, dan menyenangkan (PAKEM), tidak membosankan dan menarik bagi mahasiswa, serta yang terpenting yaitu pesan yang ingin disampaikan dosen kepada mahasiswa dapat diterima dan dipahami. 


\section{DAFTAR PUSTAKA}

Agung, Iskandar. 2010. Meningkatkan Kreativitas Pembelajaran Bagi Guru. Jakarta: Penerbit Bestari Buana Murni.

Beetlestone, Florence. 2013. Creative Learning: Strategi Pembelajaran untuk Melesatkan Kreativitas Siswa, terj. Narulita Yusron. Bandung: Penerbit Nusa Media.

Daryanto. 2013. Inovasi Pembelajaran Efektif. Bandung: Penerbit Yrama Widya.

Fathurrohman, Muhammad dan Sulistyorini. 2012. Belajar dan Pembelajaran. Yogyakarta: Teras.

Johnson, David W. et al. 2012. Colaborative Learning: Strategi Pembelajaran untuk Sukses Bersama, terj. Narulita Yusron. Bandung: Penerbit Nusa Media.

Sani, Ridwan Abdullah. 2013. Inovasi Pembelajaran. Jakarta: Bumi Aksara.

Setyarini, Sri. (2010, April). "Puppet Show": Inovasi Metode Pengajaran Bahasa Inggris dalam Upaya Meningkatkan Kemampuan Berbicara Siswa SD. Jurnal Penelitian Pendidikan Vol. 11 No. 1.

Sukmadinato, Nana Syaodeh.2008. Metode Penelitian Pendidikan. Bandung: Pt. Remaja Posdakarya.

Suparyana. (2015, 28 Oktober). Pelatihan,"Metodologi Pembelajaran Praktikum Bahasa Inggris". Kudus: Unit Pengembangan Bahasa STAIN Kudus.

Watson, Roy-Davis. 2011. Strategi Pengajaran Kreatif, terj. Theresia Aniek Setyowati Soetaryo. Jakarta: Penerbit Erlangga. 